\title{
inat \\ A Comparison in Combustion Characteristics in a CVCC with Biodiesel Blends
}

\author{
Nguyen Tuan Nghia ${ }^{1}$, Nguyen Phi Truong ${ }^{1,2, *}$, Nguyen Xuan Khoa ${ }^{1}$, Le Anh Tuan ${ }^{2}$ and Nguyen Van Tuan ${ }^{3, *}$ \\ 1 Faculty of Automobile Technology, HaNoi University of Industry, No. 298, Cau Dien Street, Bac Tu Liem \\ District, Hanoi 100000, Vietnam; nghiant@haui.edu.vn (N.T.N.); khoanx@haui.edu.vn (N.X.K.) \\ 2 Internal Combustion Engine Department, Hanoi University of Science and Technology, \\ Hanoi 100000, Vietnam; tuan.leanh@hust.edu.vn \\ 3 Mechanical Engineering Department, University of Transport Technology, No. 54 Trieu Khuc Street, \\ Thanh Xuan District, Hanoi 100000, Vietnam \\ * Correspondence: truongnp@haui.edu.vn (N.P.T.); nguyenvantuan@utt.edu.vn (N.V.T.)
}

Citation: Nghia, N.T.; Truong, N.P.; Khoa, N.X.; Tuan, L.A.; Tuan, N.V. A Comparison in Combustion Characteristics in a CVCC with Biodiesel Blends. Energies 2022, 15, 1017. https://doi.org/10.3390/ en15031017

Academic Editors: Nicu Bizon and Unai Fernández Gámiz

Received: 22 December 2021

Accepted: 28 January 2022

Published: 29 January 2022

Publisher's Note: MDPI stays neutral with regard to jurisdictional claims in published maps and institutional affiliations.

Copyright: (C) 2022 by the authors. Licensee MDPI, Basel, Switzerland. This article is an open access article distributed under the terms and conditions of the Creative Commons Attribution (CC BY) license (https:// creativecommons.org/licenses/by/ $4.0 /)$.

\begin{abstract}
This paper presents the comparison of combustion characteristics in a constant volume combustion chamber (CVCC) with alternative fuel biodiesel blends. To achieve this goal, a CVCC experimental was established, and the biodiesel was made from fish oil and was used as test fuel. The combustion process of diesel fuel (B0) and bio-diesel 10\% (B10) will be investigated based on doing experiments with two conditions: air-fuel mixed before and after ignition timing. The influence of the oxygen concentration on the burning process is also being investigated. The results of the research show that the heat release rate of B0 is faster and higher than that of B10 in the case of air-fuel mixed before ignition timing. In the case of after ignition timing, these values are almost similar to B0 and B10.
\end{abstract}

Keywords: combustion pressure raise; heat release rate; CVCC; biodiesel blends

\section{Introduction}

Current internal combustion engines are one of the main driving forces in many economic sectors, especially manufacturing and transportation. The fuel used for internal combustion engines usually consists of petroleum distillate products, such as gasoline and diesel $[1,2]$. The use of this fuel increases the need for energy [3,4] and increases the globe's environmental pollution [5-7]. Alternative fuels and energy are known as effective methods to solve this problem $[8,9]$. Biodiesel is used as a potential fuel for internal combustion engines [10-13], and it provides numerous benefits [14-19]. Biodiesel, on the other hand, can be made from a variety of common raw materials, including agricultural waste, animal fat, waste oil, and algae [20,21], and by developing biodiesel plans, developing countries can participate in sustainable agriculture $[22,23]$. When researching the fuel used for internal combustion engines, research on combustion is essential for engine optimization, including mixture formation and combustion studies, fuel injection time, ignition timing, fuel combustion time, flame spread rate, rate of pressure increase, and the equivalent ratio between fuel and air [24-26]. When studying the combustion process in the engine, there are many difficulties, such as non-transparent combustion chambers, so it is difficult to observe and take photos from the outside. In addition, the cost of designing and building the fire chamber is large. Research on mixture formation and fire in the CVCC combustion chamber will limit the many disadvantages of mixture formation and combustion in the traditional combustion chamber. Since then, the design of the constant-volume combustion chamber has been used for practical applications to improve engine productivity.

A constant volume combustion chamber is a combustion chamber with many quartz windows and throughput, so it is easy to see the inside of the chamber. Using CVCC has the advantage of being able to easily change combustion parameters, such as the air-fuel ratio, 
residual air ratio, initial pressure chamber and temperature, nozzle and spark plug position, electrode distance, and sparks. This combustion chamber is very flexible when researching, detecting the burning process, controlling the combustion process, and evaluating the process of forming mixtures and fires of different fuels $[27,28]$. The burning process of fuel in the constant volume combustion chamber has been studied in a number of projects, for example, the research of Jinyoung Jung, Sangjae Park, Choongsik Bae et al. [29] on gasoline and n-butane fuel. In this study, macro-spray imaging tests were performed in the CVCC combustion chamber under repeated ambient conditions of stratified combustion mode to achieve stable stratified combustion with gasoline and n-butane. Compared with gasoline, the structure of $n$-butane when sprayed is decomposed towards the shaft of the injector and the decay rate increases with increasing injection pressure. Additionally, unlike gasoline, $\mathrm{n}$ butane showed a similar heat transfer tendency (HRR) regardless of timing of injection and ignition. The particulate matter emissions of n-butane are almost zero, while nitrogen oxide (NOx) emissions are similar to those of gasoline. Many studies have mentioned biodiesel and its blends used in diesel engines, such as the study by KA Sateesh et al. [30], which examined the influence of $\mathrm{Al}_{2} \mathrm{O}_{3}$ nanoparticles on the properties of biodiesel. The ignition process and engine power levels of a four-stroke single-cylinder direct-injection diesel engine operating on dual fuel using DiSOME and producer gas (PG) were investigated. Engine testing showed that experiments with $\mathrm{Al}_{2} \mathrm{O}_{3}$-based nanofluid (NF) and PG-based operation resulted in $11.5 \%$ amplified brake thermal efficiency, a $23.2 \%$ reduction in smoke, and an $18.2-21.4 \%$ reduction in hydrocarbon (HC) and carbon monoxide (CO) emissions, while a significantly higher nitric oxide level (NOx) of 32.6\% was achieved compared to the same fuel combination excluding NP at 80\% load. Manzoore Elahi M. Soudagar et al. [31] presented diesel engines using biofuels produced from Moringa oleifera oil. A blend of B10 and B20 biodiesel was tested in a combustion compression engine, and the performance and emissions characteristics were analyzed and compared with a diesel engine. The engine operates at full load with an engine speed varying from $1000 \mathrm{rpm}$ to $2400 \mathrm{rpm}$. All performance and pollutant emissions results were collected and analyzed. It was found that MOB10 produced lower brake power (BP) $(7.44 \%)$, BSFC (7.51\%), and $\mathrm{CO}_{2}(7.7 \%)$. MOB10 also reduces smoke opacity by $24 \%$ and $\mathrm{HC}$ by $10.27 \%$. Compared with diesel engines, MOB10 also increases $\mathrm{CO}(2.5 \%)$ and $\mathrm{NOx}(9 \%)$. In other article, the preparation of biodiesel from cottonseed oil and its blending with octanol were presented [32]. The heat and mass transfer properties of biodiesel have been further improved by the addition of multi-walled carbon nanotubes (MWCNTs). Experiments were carried out with four cottonseed oil blends (B20, B40, B60, and B100) that were prepared initially, and each blend was added with $5 \%, 10 \%$, and $15 \%$ octanol additives and 3\% MWCNT. Performance analysis shows that B20 with 5\%,10\%, and 15\% octanol exhibits relatively lower specific fuel consumption compared to all test fuels. On the other hand, the addition of MWCNT nanoparticles has further stabilized fuel consumption rates and engine thermal efficiency. At higher values of the diesel and biodiesel blends, performance and emissions are the same.

Ji Zhang et al. also studied the burning properties of vegetable oils with different blend ratios $(20 \%, 50 \%$, and $100 \%)$ compared with diesel fuel in the constant volume combustion chamber [33]. The results showed that the heat transfer of the vegetable oil fuel and its percentage components has the same results as that of diesel fuel under the same conditions of injection pressure, temperature, and ambient pressure. Kitamura et al. [34] studied experimentally the influence of oxygen concentration on the diesel combustion process in a diesel-burning CVCC in simulated conditions. The results show that reducing the oxygen concentration to $18 \%$ and $15 \%$ has no effect on the exothermic rate, but it largely affects Nox emissions.

Through the analysis of the above studies, the authors found that using a constant volume combustion chamber has many advantages for studying the combustion of the engine, such as the advantage of the ability to easily change combustion parameters, such as the air-fuel ratio, the ratio of excess air, the pressure inside the combustion chamber, and the temperature. This combustion chamber is very flexible when it comes to researching 
and detecting combustion, controlling the combustion process, and evaluating mixture formation and combustion of different fuels. The HCCI fire model with the advantages of high thermal efficiency and very small NOx and PM emissions is one of the research and development directions of engines in the future. This fire model is born that can ensure the strict requirements for emissions and reduce the pressure on fuel sources from oil, because this type of engine is very suitable for using alternative fuels of biological origin [35,36]. The HCCI engine has the above advantages because it combines the advantages of both diesel engines (thermal efficiency) and gasoline engines (emissions). The engine has no throttle on the intake and works with light blends. These factors improve thermal efficiency. When a homogeneous mixture is created, there are no local areas with a high fuel density. Therefore, the process of diffuse combustion does not take place, reducing PM particle emissions $[37,38]$.

This paper presents the combustion process in a constant volume combustion chamber when the mixture is mixed in two cases, pre-mixing and post-mixing, with diesel fuel and bio-diesel $10 \%$. With the evolution of the combustion process, the pressure in the cylinder and the heat release rate of the test combustion chamber running on the biodiesel mixture are compared with the combustion chamber running on standard diesel fuel. The main purpose of this work is to compare the combustion characteristics of a CVCC with biodiesel blends in two cases: pre-mixing and post-mixing. In addition, optimization of engine operating parameters is also carried out to improve engine characteristics with different blends of biodiesel fuel.

\section{Experimental Procedure}

\subsection{Test Chamber Combustion}

The combustion chamber used in this study is a constant volume combustion chamber. This combustion chamber has many transparent and quartz doors, so it is easy to see the inside of the chamber. Table 1 shows the specifications of the combustion chamber. The CVCC combustion chamber has its own fuel and gas supply system. Therefore, it is easy to change the boundary conditions (temperature, pressure, and fire time) of the combustion process and can be researched for many different fuels.

Table 1. Constant volume combustion chamber parameters.

\begin{tabular}{ccc}
\hline Parameter & Values & Unit \\
\hline Outer diameter & 200 & $\mathrm{~mm}$ \\
\hline Inner diameter & 80 & $\mathrm{~mm}$ \\
\hline Cylinder length & 90 & $\mathrm{~mm}$ \\
\hline Supply air maximum pressure & 80 & $\mathrm{bar}$ \\
\hline Common rail fuel supply system & 200 & $\mathrm{Mpa}$ \\
\hline
\end{tabular}

\subsection{Test Fuels}

In this study, the test fuel is fossil diesel fuel, and the biodiesel fuel is palm oil. The fatty acid components of biodiesel are presented in Table 2. Some physical and chemical properties of the test fuel corresponding to B0 and B10 are presented in Table 3. Fuel B10 has a volume percentage of $10 \%$. The parameters of some physical and chemical properties of the fuel are determined by a specialized unit by the Institute of Industrial Chemistry of Vietnam. B10 fuel is a blend of $90 \%$ by volume of B0 and $10 \%$ by volume of B100. 
Table 2. Fatty acid profile of biodiesel used in this research.

\begin{tabular}{cc}
\hline Fame & Fame Composition (\%) \\
\hline $\mathrm{C}_{16} \mathrm{H}_{32} \mathrm{O}_{2}$ & 28.09 \\
\hline $\mathrm{C}_{18} \mathrm{H}_{32} \mathrm{O}_{2}$ & 18.02 \\
\hline $\mathrm{C}_{18} \mathrm{H}_{34} \mathrm{O}_{2}$ & 43.47 \\
\hline $\mathrm{C}_{18} \mathrm{H}_{36} \mathrm{O}_{2}$ & 9.53 \\
\hline Other & 0.89 \\
\hline
\end{tabular}

Table 3. Comparison of biodiesel blend and diesel fuel properties.

\begin{tabular}{cccc}
\hline Property & Unit & B0 & B10 \\
\hline Heating value & $\mathrm{MJ} / \mathrm{kg}$ & 42.76 & 42.39 \\
\hline Cetane No & - & 49 & 48 \\
\hline Density & $\mathrm{kg} / \mathrm{m}^{3}$ & 838 & 847 \\
\hline Kinematic viscosity at $40^{\circ} \mathrm{C}$ & $\mathrm{mm}^{2} / \mathrm{s}$ & 3.22 & 3.61 \\
\hline Flash point & ${ }^{\circ} \mathrm{C}$ & 67 & 75 \\
\hline Sulfur & $\mathrm{ppm}$ & 428 & 431 \\
\hline Water content & $\mathrm{ppm}$ & 62 & 83 \\
\hline
\end{tabular}

\subsection{Test Equipment}

The AVL FLEXIFEM pressure measuring device and the AVL GH13Z-31 cylinder pressure sensor measure pressure changes in cylinders. This is a pressure sensor type GH13Z-31 from AVL, a pressure sensor mounted directly to the combustion chamber body to measure the pressure in the cylinder of the combustion chamber. This is a quartz pressure sensor that detects the pressure in the cylinder through the polarized quartz crystals, creating an electric field in the crystal with the basic parameters as shown in Table 4 below.

Table 4. Specification of the GH13Z-31 sensor.

\begin{tabular}{cc}
\hline Stable working pressure range & $0 \div 25 \mathrm{bar}$ \\
\hline Error & $\pm 0.3 \%$ \\
\hline Stable working temperature & $-40 \div 400{ }^{\circ} \mathrm{C}$ \\
\hline Sensitivity & $16 \mathrm{pC}$ bar \\
\hline
\end{tabular}

A Chrónos 4.1 high-speed camera can capture up to 40,000 frames/ sec, and was used to capture the entire burning process in real time.

The CVCC test chamber can observe the burning process from the outside through an observation glass.

Balance of fuel: The amount of fuel that the vehicle consumes is measured with a fuel consumption measuring device, fuel balance AVL 733S, using the weight method. The system fuel allows for highly accurate fuel consumption measurements, even at low consumption and short measurement times. The measuring range of the device is up to $150 \mathrm{~kg} / \mathrm{h}$ with an accuracy of $0.12 \%$.

\subsection{Experimental Setup}

Diesel fuel is put into the combustion chamber and mixed first with the gas mixture $\left(\mathrm{C}_{2} \mathrm{H}_{2}, \mathrm{O}_{2}\right.$, and $\left.\mathrm{N}_{2}\right)$ in the combustion chamber with a certain percentage, ensuring that the percentage of moles of oxygen after reacting with $\mathrm{C}_{2} \mathrm{H}_{2}$ is $20 \%$ in the combustion product. The amount of oxygen supplied must be such that the ratio $\mathrm{A} / \mathrm{F}=1.2$. Experimental 
fuel injection is done at high pressure (1500 bar). After closing all valves and starting the mixing process (turning on the fan to mix the gas and fuel mixture), igniting the electric spark ignites the mixture of gas and test fuel. Images of combustion in the combustion chamber were taken with the high-speed camera Chrónos 4.1 (camera captures up to 40,000 frames/second). The pressure of the combustion chamber was measured with AVL QQ33C cylinder pressure sensor and recorded with the AVL pressure gauge FLEXIFEM.

The experimental condition was to ensure that the fuel is mixed uniformly and that combustion takes place. Operating a three-phase electric motor running at a steady $15 \mathrm{~Hz}$ frequency corresponds to a pump rotational speed of $900 \mathrm{rpm}$, which ensured that the fuel system pressure is satisfactory and that the injector pressure reaches 1500 bar. To ensure that the ratio between fuel and air does not depend on the outside air condition, it needs to be in a vacuum and the initial pressure for the combustion chamber needs to be set. The intake air control system is responsible for loading the gases in the mixture $\left(\mathrm{C}_{2} \mathrm{H}_{2}, \mathrm{~N}_{2}\right.$, and $\mathrm{O}_{2}$ ) in turn into the combustion chamber so that the amount of oxygen after the reaction is $20 \%$. In the case of blending before the CNLM time, a combustion chamber temperature of $450 \mathrm{~K}$ will ensure that the fuel evaporates when it is injected into the combustion chamber. The time of fuel injection before the time of priming fuel injection will help the fuel to be mixed longer with the gas mixture inside the combustion chamber. The fan mixes before the fuel injection time 2 (s) and ends when the primer fuel starts to burn. Combined with a very-high-speed mixing fan, the mixture is homogenized in CVCC before self-ignition (HCCI). The experimental conditions are shown in Table 5.

Table 5. Experimental conditions.

\begin{tabular}{cc}
\hline Parameter & Condition \\
\hline Fuel & Diesel, bio-diesel $10 \%$ \\
\hline Nozzle diameter & $0.14(\mathrm{~mm})$ \\
\hline Spray time & $3(\mathrm{~ms})$ \\
\hline Spray pressure & $150 \mathrm{MPa}$ \\
\hline Environment temperature & $297 \mathrm{~K}$ \\
\hline Oxygen concentration & $20 \%$ \\
\hline Number of experiments & 10 \\
\hline
\end{tabular}

\section{Experimental Layout Diagram}

Image acquisition system is shown in Figure 1: Layout of a combustion image information collection system in CVCC. The experimental arrangement diagram andcombustion chamber of the CVCC system is presented in Figures 2 and 3.

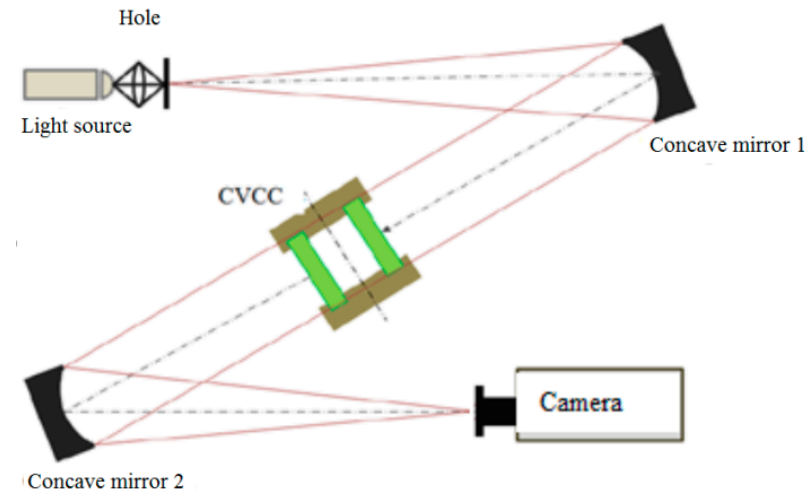

Figure 1. Image acquisition scheme. 


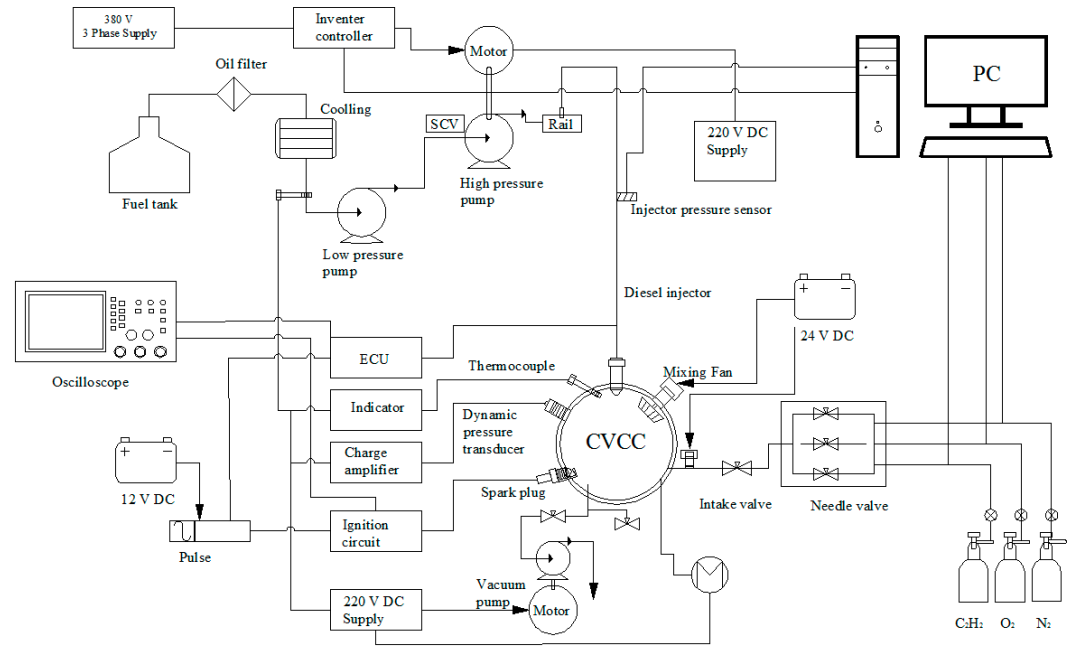

Figure 2. Experimental arrangement diagram of the CVCC system.

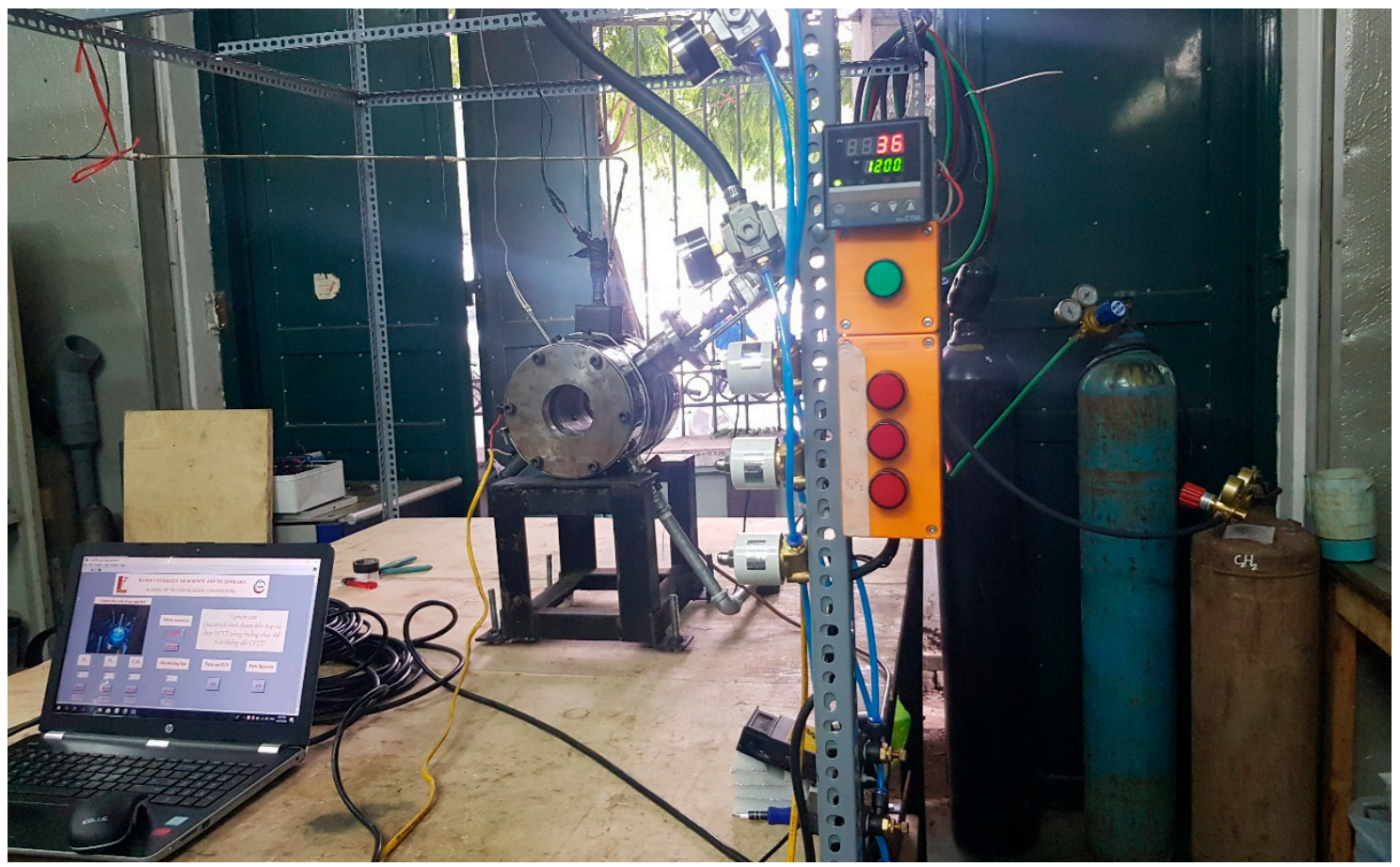

Figure 3. Constant volume combustion chamber.

\section{Results and Discussion}

The combustion in the constant volume combustion chamber (CVCC) takes place in two phases. The first stage is to burn gas mixtures $\left(\mathrm{C}_{2} \mathrm{H}_{2}, \mathrm{~N}_{2}\right.$, and $\left.\mathrm{O}_{2}\right)$ to create an initial pressure and temperature to create burning conditions for fuel injection. The second stage is to burn diesel fuel or bio-diesel fuel injected into the combustion chamber. Below, we go into the specific details of the combustion process. The results of this study are shown in the imaging of the combustion chamber, which shows the spread of the flame film in the combustion chamber according to the HCCI principle with complete mixing of the mixture before and after the ignition.

\subsection{Pri-Mixture before Ignition}

\subsubsection{Flame Membrane Development}

Figure 4 shows the spread of the flame film in the constant volume combustion chamber of the two tested fuels. For B0 fuel, the image from the appearance of the spark to 
the propagation of the entire combustion chamber is four images from a time of $1-4$ ms. For $10 \%$ bio-diesel fuel (B10), there are five images from time 1-5 ms. Thus, it can be seen that the flame spread rate of diesel fuel (B0) is much higher than that of bio-diesel fuel (B10).

\begin{tabular}{|c|c|c|c|c|c|}
\hline Time (ms) & Diesel (B0) & Bio-diesel 10\% (B10) & Time (ms) & Diesel (B0) & Bio-diesel 10\% (B10) \\
\hline 1 & & & 7 & & \\
\hline 2 & & & 8 & & \\
\hline 3 & & $\overline{78}$ & 9 & & \\
\hline 4 & & 8 & 10 & & \\
\hline 5 & & & 11 & & \\
\hline 6 & & & 12 & & \\
\hline
\end{tabular}

Figure 4. Image of pilot combustion spreading the flame film of the fuel in a constant volume combustion chamber (diesel (B0), 10\% bio-diesel (B10)).

Specifically, diesel and bio-diesel fuel have flame membrane lengths of $44(\mathrm{~mm})$ and $17(\mathrm{~mm})$, respectively. Figures 5 and 6 show that the flame spread rate of diesel fuel is about two times higher than that of bio-diesel fuel, which is $10 \%$. The reason is that diesel fuel has a higher low calorific value, a lower flash point, lower viscosity, and better air-conditioning quality, resulting in faster flame film propagation.

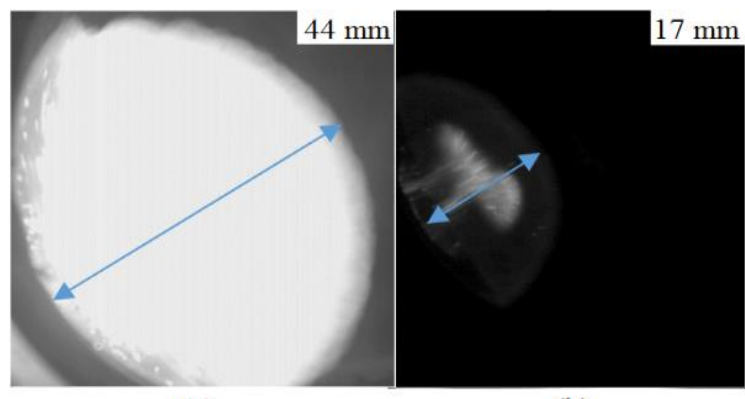

(a)

(b)

Figure 5. Film propagation speed at 3 ms after ignition; (a) diesel; (b) bio-diesel 10\%. 


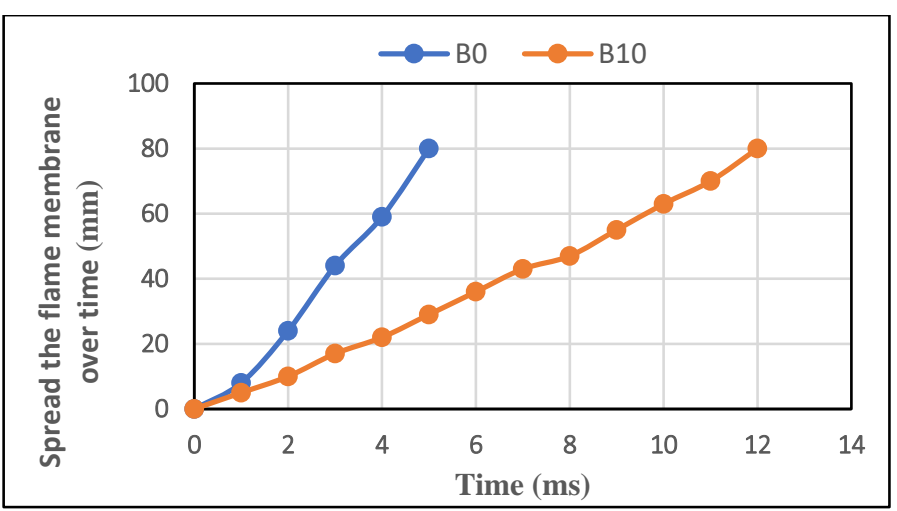

Figure 6. Spread of the flame membrane over time in the CVCC combustion chamber.

\subsubsection{Evolution of the Pressure in the Cylinder}

We studied the premixed fuel mixtures in the CVCC combustion chamber. Figure 7 shows an earlier combustion pressure of diesel fuel, a shorter delay time, and a greater slope than bio-diesel fuel of 10\% (B10). This may be because diesel fuel has a higher low-calorific value and, therefore, a higher pressure. The more ventricular viscosity should be mixed at a higher peak pressure rise rate. Because of the lower flash point and shorter mixing time, the fuel burns faster and has a higher peak pressure than 10\% biodiesel fuel (B10).

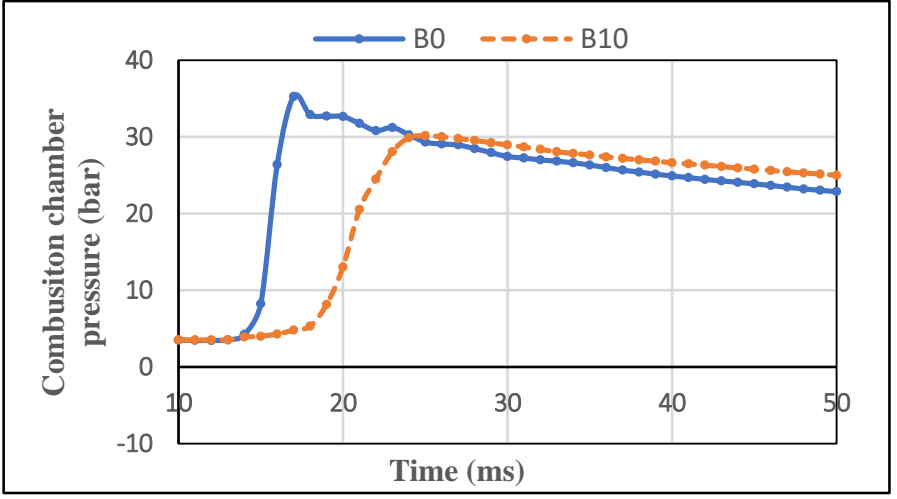

Figure 7. Pressure evolution of test fuel in the CVCC combustion chamber.

\subsubsection{The Rising Pressure Rate}

Figure 8 shows that the rate of increase in pressure of diesel fuel took place earlier and higher than that of bio-diesel fuel, as shown in the pressure slope of the two fuels. This means the diesel-air-fuel mixture has a higher homogeneity and is much more volatile than the 10\% bio-diesel fuel (B10)-air blend, which means speed, higher heat generation, faster, and earlier finish of the diesel-air mixture compared to the 10\% (B10)-air bio-diesel blend. In the first phase, the rate of increase in pressure of diesel fuel increases very rapidly (from $14 \mathrm{~ms}$ to $16 \mathrm{~ms}$ ) to reach peak pressure, while for bio-diesel fuel, the pressure increase process has not taken place yet output (the late fire phase takes place more slowly). This is clearly shown in the percent of combined fuel. 


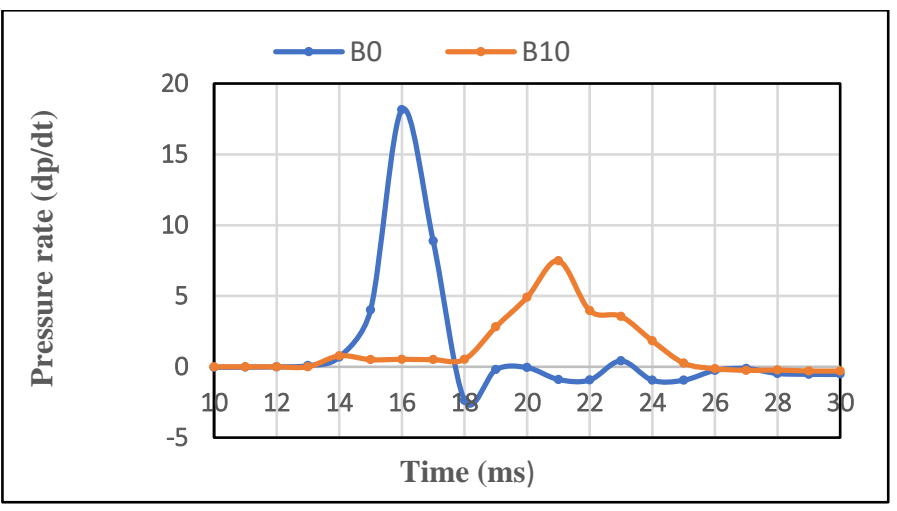

Figure 8. Rate of increase in pressure in the CVCC combustion chamber before the time of ignition.

Figure 9 shows that the percentage of burned fuel of $\mathrm{B} 0$ fuel reaches its maximum value earlier and faster than $10 \%$ bio-diesel fuel (B10) in the early stages of combustion. Then, it tapered off and was smaller than fuel B10. The reason is that the higher viscosity of B10 fuel is more difficult to mix in the early stages, but in the later stages, a higher percentage of the B10 fuel burned because of the oxygen content inside the fuel.

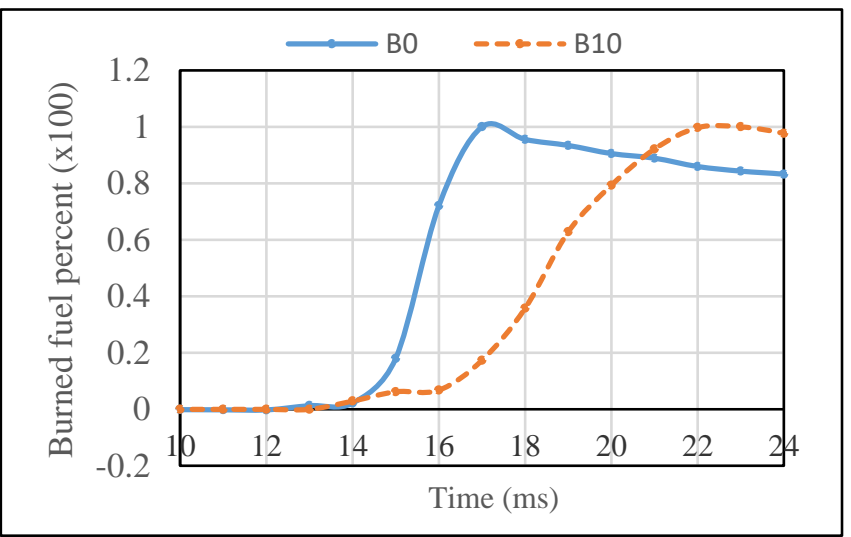

Figure 9. Graph of the \% fuel burned.

\subsubsection{Heat Release Rate}

Figure 10 shows that the heat generation of diesel fuel (B0) takes place earlier, has a higher heat rate, and finishes faster than the bio-diesel fuel (B10). In the figure, we see that the exothermic value of $\mathrm{B} 0$ is higher and earlier than that of $\mathrm{B} 10$. The main reason is the low calorific value and flash point of B0 fuel compared to B10 fuel.

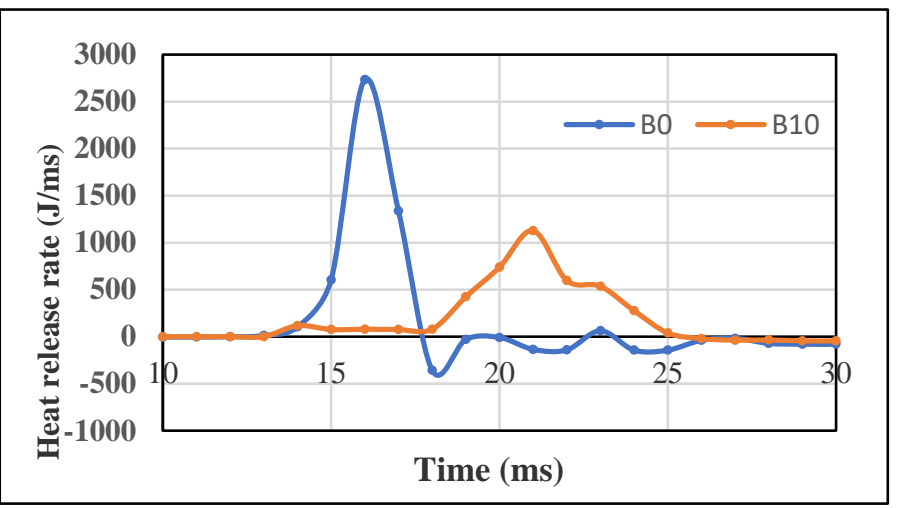

Figure 10. Heat release rate of fuel in CVCC. 


\subsection{The following Mix Is Mixed}

\subsubsection{Flame Membrane Development}

Figure 11 shows the flame film spread and light intensity in a constant volume combustion chamber of the two tested fuels. For B0 and B10 fuels, the image from the time the spark appears to the entire combustion chamber is 12 pictures. Thus, it can be seen that the spread rate of diesel fuel (B0) is 10\% higher than that of bio-diesel fuel (B10), but this value does not change much. Those figures were captured after $1 \mathrm{~ms}$. The flame membrane development can be observed.

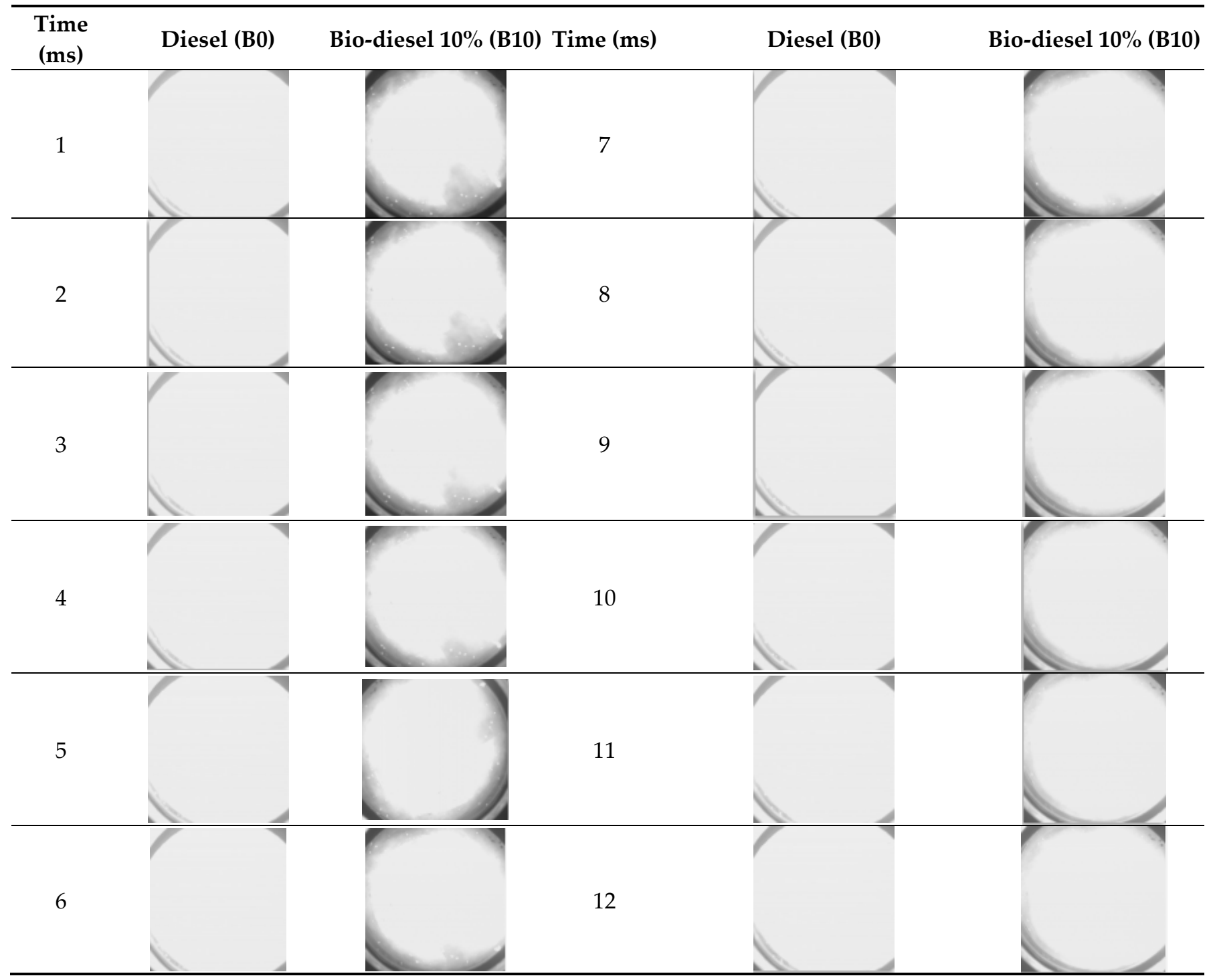

Figure 11. Progression of pressure in the CVCC combustion chamber.

\subsubsection{Pressure in the CVCC Combustion Chamber}

Figure 12 shows that the pressure changes in the cylinder for all fuels tested in all modes have similar rules to those in traditional diesel engines. The beginning of the rapid increase in pressure corresponds to the earlier end of the biodiesel fuel's low combustion phase. Peak pressures tend to shift to the left (shorter time) and have a lower value as the biodiesel blend ratio increases. The reason is that 10\% bio-diesel fuel (B10) has a higher solubility value, so the preparation time for combustion is shorter. The peak pressure of the $10 \%$ bio-diesel fuel is slightly lower because the low calorific value of the $10 \%$ bio-diesel fuel is lower than that of diesel fuel. 


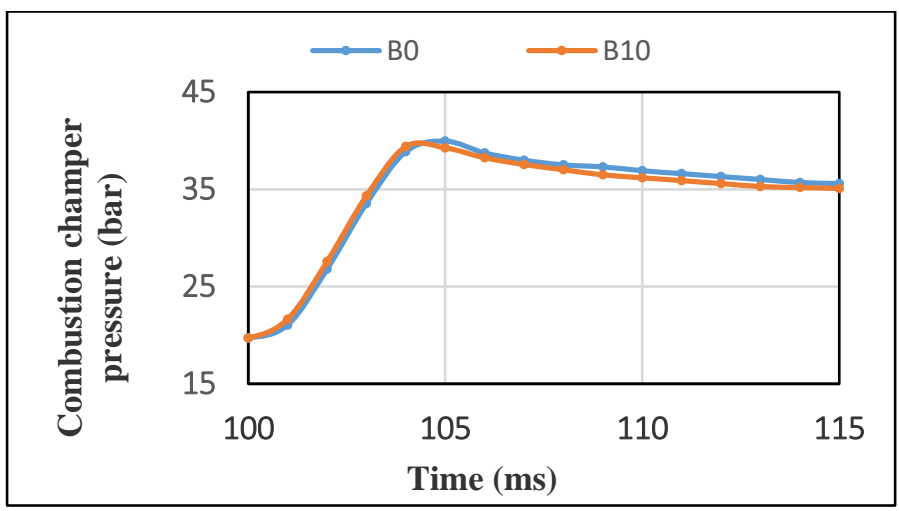

Figure 12. Progression of pressure in the CVCC combustion chamber.

\subsubsection{Combustion Pressure Raise}

The rate of pressure increase of the test fuel is shown in Figure 13, which shows that the law of increasing pressure in the combustion chamber of two fuels has the same law. Specifically, the rate of increase in pressure of fuel B10 takes place earlier and reaches a smaller value than that of fuel B0. The main cause is the properties of the fuel. Specifically, the properties of low calorific value and dissipation value directly affect the rate of increase in pressure of the two fuels.

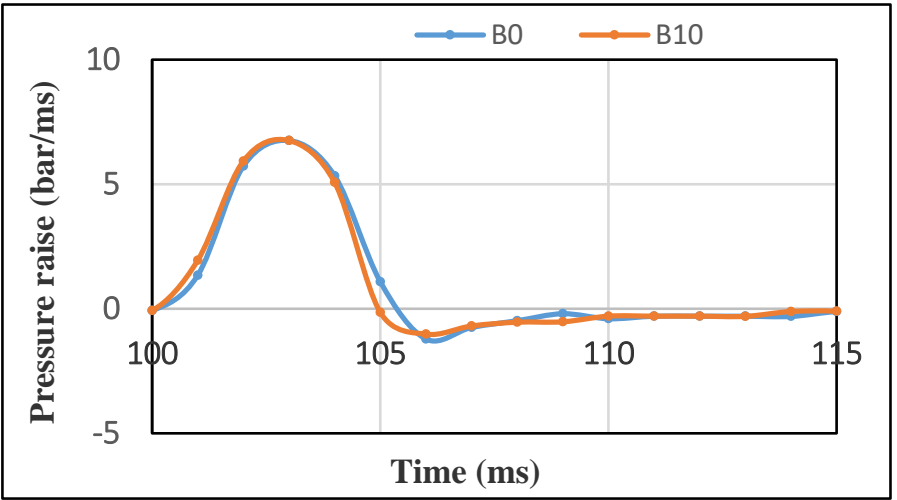

Figure 13. Pressure raise in CVCC.

\subsubsection{Heat Release Rate}

Biodiesel fuel with a higher viscosity makes it difficult to mix the mixture, resulting in a shorter mixture of air and fuel prepared during a shorter delay phase, leading to rapid combustion; it took place earlier. The lower peak pressure compared to when using diesel fuel is due to the lower calorific value. This is also shown for the evolution of the heat rate in the combustion chamber cylinder (Figure 14). The principle of the evolving rate of heat in a cylinder is similar to that of evolution in pressure. Specifically, the value of B0 fuel's heat is greatest and decreases gradually when the blending ratio of biodiesel increases (Figure 13). 


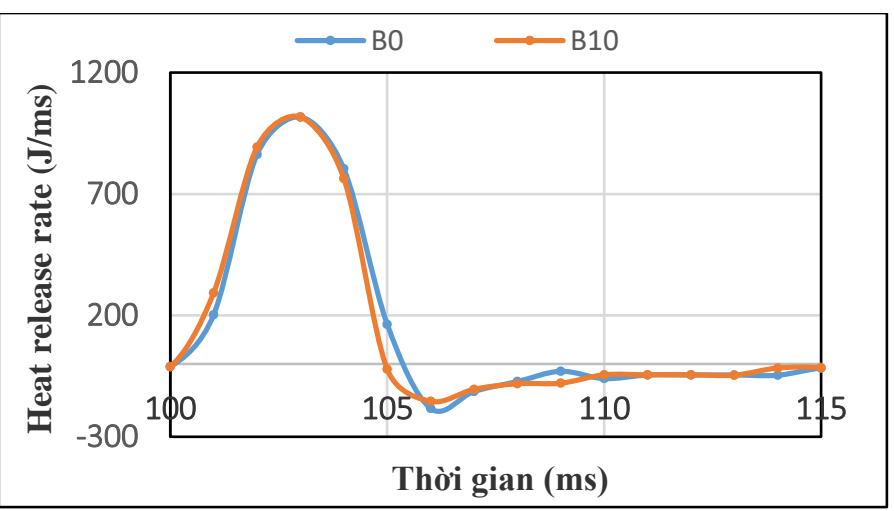

Figure 14. Evolution of the exothermic rate of the test fuel.

\subsubsection{Percent of Burned Fuel}

Figure 15 shows that B10 fuel burns earlier and burns $100 \%$ of the fuel earlier than B0 fuel. This may be due to the shorter 10\% bio-diesel fuel mixture preparation time and higher solubility value. Then, it gradually decreases and gets smaller in the remaining combustion phases of combustion. This is probably due to the higher bio-diesel fuel viscosity, which makes the post-burn period longer than that of traditional diesel fuel.

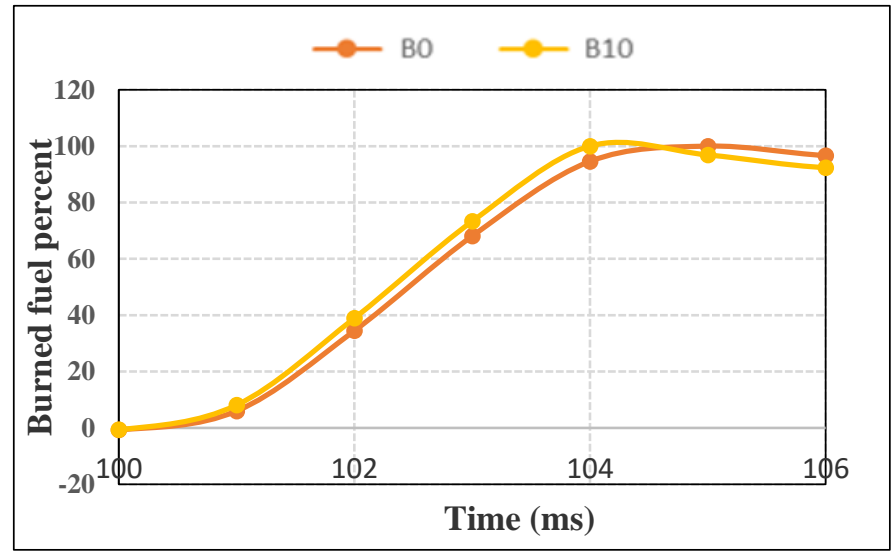

Figure 15. Evolution \% of the fuel burn test.

\section{Conclusions}

When studying the combustion of two types of diesel fuel (B0) and bio-diesel 10\% (B10) in a constant volume combustion chamber, the authors come to the following conclusions.

When studying the flame propagation speed of two fuels, the mixture before ignition, under the same study conditions, the flame film spread rate of diesel fuel was about 2.6 times higher than that of bio-diesel fuel. The combustion of diesel fuel takes place earlier and reaches its maximum pressure value earlier; the rate of increase in pressure is $10 \%$ faster in the late combustion period compared to bio-diesel fuel. The percentage of diesel fuel burned takes place earlier and reaches its maximum value $10 \%$ earlier than bio-diesel fuel.

The cylinder pressure evolution for the test fuel has similar rules and is similar to that in traditional engines. This means that the bio-diesel fuel's delayed combustion pressure of $10 \%$ occurs earlier, peaks earlier, and ends earlier than conventional diesel fuel. The bio-diesel fuel's pressure rise rate of $10 \%$ occurs earlier and peaks earlier than the traditional diesel fuel. The heat rate has a law similar to the law of increasing pressure. Specifically, the value of the heat rate of diesel fuel is $10 \%$ greater than that of bio-diesel fuel.

In the future, the authors will focus on optimizing the engine operation parameters with various biodiesel blends to improve engine performance. In addition, observations of 
the combustion of diesel engines and their changes when using biodiesel blends will be investigated.

Author Contributions: Data curation, N.T.N., N.P.T., L.A.T. and N.V.T.; Formal analysis, N.P.T., N.X.K., L.A.T. and N.V.T.; Investigation, L.A.T. and N.V.T.; Methodology, N.T.N., N.P.T., N.X.K. and L.A.T.; Software, N.V.T.; Validation, N.T.N.; Writing-original draft, N.P.T.; Writing-review \& editing, N.X.K. All authors have read and agreed to the published version of the manuscript.

Funding: This research received no external funding.

Institutional Review Board Statement: Not applicable.

Informed Consent Statement: Not applicable.

Data Availability Statement: Not applicable.

Conflicts of Interest: The authors declare no conflict of interest.

\section{References}

1. Sahoo, B.B.; Saha, U.K.; Sahoo, N. Theoretical performance limits of a syngas-diesel fueled compression ignition engine from second law analysis. Energy 2011, 36, 760-769. [CrossRef]

2. Wagemakers, A.M.L.M.; Leermakers, C.A.J. Review on the Effects of Dual-Fuel Operation, Using Diesel and Gaseous Fuels, on Emissions and Performance. SAE Int. J. Engines 2012. [CrossRef]

3. Deng, Y.; Liu, H.; Zhao, X.; E, J.; Chen, J. Effects of cold start control strategy on cold start performance of the diesel engine based on a comprehensive preheat diesel engine model. Appl. Energy 2018, 210, 279-287. [CrossRef]

4. $\quad$ E, J.; Zang, Z.; Tu, Z.; Zuo, W.; Hu, W.; Han, D.; Jin, Y. Effect analysis on flow and boiling heat transfer performance of cooling water-jacket of bearing in the gasoline engine turbocharger. Appl. Therm. Eng. 2018, 130, 754-766. [CrossRef]

5. Zhang, B.; E, J.; Gong, J.; Yuan, W.; Zuo, W.; Li, Y.; Fu, J. Multidisciplinary design optimization of the diesel particulate filter in the composite regeneration process. Appl. Energy 2016, 181, 14-28. [CrossRef]

6. E, J.; Zuo, W.; Gao, J.; Peng, Q.; Zhang, Z.; Pham, M. Effect analysis on pressure drop of the continuous regeneration-diesel particulate filter based on $\mathrm{NO}_{2}$ assisted regeneration. Appl. Therm. Eng. 2016, 100, 356-366. [CrossRef]

7. E, J.; Han, D.; Deng, Y.; Zuo, W.; Qian, C.; Wu, G.; Peng, Q.; Zhang, Z. Performance enhancement of a baffle-cut heat exchanger of exhaust gas recirculation. Appl. Therm. Eng. 2018, 134, 86-94. [CrossRef]

8. Dincer, I.; Rosen, M.A. Thermodynamic aspects of renewables and sustainable development. Renew. Sustain. Energy Rev. 2005, 9 , 169-189. [CrossRef]

9. Bundschuh, J.; Chen, G.; Yusaf, T.; Chen, S.; Yan, J. Sustainable energy and climate protection solutions in agriculture. Appl. Energy 2014, 114, 735-736. [CrossRef]

10. Wen, Z.; Yu, X.; Tu, S.T.; Yan, J.; Dahlquist, E. Synthesis of biodiesel from vegetable oil with methanol catalyzed by Li-doped magnesium oxide catalysts. Appl. Energy 2010, 87, 743-748. [CrossRef]

11. Cynthia, O.B.; Lee, K.T.; Lim, J.K. Comparative exergy analyses of Jatropha curcas oil extraction methods: Solvent and mechanical extraction processes. Energy Convers. Manag. 2012, 55, 164-171.

12. Lim, S.; Lee, K.T. Investigation of impurity tolerance and thermal stability for biodiesel production from Jatropha curcas L. seeds using supercritical reactive extraction. Energy 2014, 68, 71-79. [CrossRef]

13. Aghbashlo, M.; Demirbas, A. Biodiesel: Hopes and dreads. Biofuel Res. J. 2016, 3, 379. [CrossRef]

14. Tabatabaei, M.; Karimi, K.; Horvath, I.S.; Kumar, R. Recent trends in biodiesel production. Biofuel Res. J. 2015, 2, $258-267$. [CrossRef]

15. Sharma, Y.C.; Singh, B.; Madhu, D.; Liu, Y.; Yaakob, Z. Fast synthesis of high quality biodiesel from 'waste fish oil' by single step transesterification. Biofuel Res. J. 2014, 1, 78-80. [CrossRef]

16. Kannan, G.R.; Anand, R. Effect of injection pressure and injection timing on DI diesel engine fuelled with biodiesel from waste cooking oil. Biomass Bioenergy 2012, 46, 343-352. [CrossRef]

17. Hoekman, S.K.; Robbins, C. Review of the effects of biodiesel on NOx emissions. Fuel Process. Technol. 2012, 96, 237-249. [CrossRef]

18. Enweremadu, C.C.; Rutto, H.L. Combustion, emission and engine performance characteristics of used cooking oil biodieseldA review. Renew. Sustain. Energy Rev. 2010, 14, 2863-2873. [CrossRef]

19. Khalife, E.; Tabatabaei, M.; Demirbas, A.; Aghbashlo, M. Impacts of additives on performance and emission characteristics of diesel engines during steady state operation. Prog. Energy Combust. Sci. 2017, 59, 32-78. [CrossRef]

20. Dias, J.M.; Alvim-Ferraz, M.C.M.; Almeida, M.F.; Díaz, J.D.M.; Polo, M.S.; Utrilla, J.R. Biodiesel production using calcium manganese oxide as catalyst and different raw materials. Energy Convers. Manag. 2013, 65, 647-653. [CrossRef]

21. Rattanapoltee, P.; Kaewkannetra, P. Cultivation of microalga, Chlorella vulgaris under different autoeheteroemixo trophic growths as a raw material during biodiesel production and cost evaluation. Energy 2014, 78, 4-8. [CrossRef] 
22. Piastrellini, R.; Arena, A.P.; Civit, B. Energy life-cycle analysis of soybean biodiesel: Effects of tillage and water management. Energy 2017, 126, 13-20. [CrossRef]

23. Kuss, V.V.; Kuss, A.V.; Rosa, R.G.D.; Aranda, D.A.G.; Cruz, Y.R. Potential of biodiesel production from palm oil at Brazilian Amazon. Renew. Sustain. Energy Rev. 2015, 50, 1013-1020. [CrossRef]

24. Sinha, S.; Agarwal, A.S. Combustion Characteristics of Rice Bran Oil Derived Biodiesel in a Transportation Diesel Engine. SAE Pap. 2005, 26, 354.

25. Senatore, A.; Cardone, M.; Rocco, V.; Prati, M.V. A Comparative Analysis of Combustion Process in D. I. Diesel Engine Fueled with Biodiesel and Diesel Fuel. Trans. SAE 2000. [CrossRef]

26. van Gerpen, J.H.; Hammond, E.G.; Yu, L.; Monyem, A. Determining the influence of contaminants on Biodiesel Properties. SAE Pap. 1997, 971685. [CrossRef]

27. Hajialimohammadi, A.; Ahmadisoleymani, S.; Abdullah, A.; Asgari, O.; Rezai, F. Design And Manufacturing of A Constant Volume Test Combustion Chamber For Jet And Flame Visualization of CNG Direct Injection. Appl. Mech. Mater. 2012, 217-219, 2539-2545. [CrossRef]

28. Srichai, P.; Chareonphonphanich, C.; Karin, P.; Chollacoop, N. Design Concept of Biodiesel Direct Injection Constant Volume Combustion Chamber. In Proceedings of the 3rd TSME International Conference on Mechanical Engineering, Chiang Rai, Thailand, 24-27 October 2012.

29. Jung, J.; Park, S.; Bae, C. Combustion characteristics of gasoline and n-butane under lean stratified mixture conditions in a spray-guided direct injection spark ignition engine. Fuel 2017, 187, 146-158. [CrossRef]

30. Sateesh, K.A.; Yaliwal, V.S.; Soudagar, M.E.M.; Banapurmath, N.R.; Fayaz, H.; Safaei, M.R.; Elfasakhany, A.; El-Seesy, A.I. Utilization of biodiesel $/ \mathrm{Al}_{2} \mathrm{O}_{3}$ nanoparticles for combustion behavior enhancement of a diesel engine operated on dual fuel mode. J. Therm. Anal. 2021, 1-15. [CrossRef]

31. Soudagar, M.; Khan, H.; Khan, T.; Razzaq, L.; Asif, T.; Mujtaba, M.; Hussain, A.; Farooq, M.; Ahmed, W.; Shahapurkar, K.; et al. Experimental Analysis of Engine Performance and Exhaust Pollutant on a Single-Cylinder Diesel Engine Operated Using Moringa Oleifera Biodiesel. Appl. Sci. 2021, 11, 7071. [CrossRef]

32. Soudagar, M.E.M.; Afzal, A.; Safaei, M.R.; Manokar, A.M. Investigation on the effect of cottonseed oil blended with different percentages of octanol and suspended MWCNT nanoparticles on diesel engine characteristics. J. Therm. Anal. Calorim. 2021, 147, 525-542. [CrossRef]

33. Marasri, S.; Ewphun, P.-P.; Srichai, P. Experimental Investigation on Combustion Characteristics of Hydrotreated Vegetable Oil (HVO)-Diesel Blended Fuels in Constant Volume Combustion Chamber (CVCC). In Proceedings of the JSAE Annual Congress (Spring), Yokohama, Japan, 18-26 May 2017.

34. Kitamura, Y.; Mohammadi, A.; Ishiyama, T.; Shioji, M. Fundamental Investigation of NOx Formation in Diesel Combustion Under Supercharged and EGR Conditions. SAE Int. 2005, 13. [CrossRef]

35. Bendu, H.; Sivalingam, M. Experimental investigation on the effect of charge temperature on ethanol fueled HCCI combustion engine. J. Mech. Sci. Technol. Pap. 2016, 30, 4791-4799. [CrossRef]

36. Noguchi, M.; Tanaka, Y.; Tanaka, T.; Takeuchi, Y. A study on gasoline engine combustion by observation on intermediate reactive products during combustion. SAE Pap. 1979, 2816-2828. [CrossRef]

37. Herbinet, O.; Pitz, W.J.; Westbrook, C.K. Detailed chemical kinetic oxidation mechanism for a biodiesel surrogate. Combust. Flame 2008, 154, 507-528. [CrossRef]

38. Szybist, J.; Song, J.; Alam, M.; Boehman, A.L. Biodiesel combustion, emissions and emission control. Fuel Process. Technol. 2007, 88, 679-691. [CrossRef] 